\title{
209. Chemical Composition of Chromogranules Produced in the Hypodermal Cells of Silkworm Larvae*)
}

By Mitsuo Tsujita and Susumu SakuraI

(Comm. by Yoshimaro TanaKa, M.J.A., Oct. 12, 1966)

In our preceding paper the structure of chromogranules was dealt with. The present paper deals with the determination of the chemical composition of chromogranules.

Materials and methods. Daizo, C-124, E-lem, d-lem, and $w^{o x}$ strains were used. The isolation method of mature chromogranules from the larval hypodermal cells was described in our preceding paper (in the press). The separated chromogranules were lyophilized.

On the other hand, the larval hypodermis of each of the strains was dried and ground to powder. The isolated chromogranules and the powdered hypodermis were used for the determination of RNA amount. RNA, protein, and lipid fractions were prepared from purified chromogranules according to the procedure of Schmidt-Thannhauser and Schneider (1946), and the RNA amount was determined by the orcinol method of Mejbaum (1939).

Protein and lipid fractions were dried to constant weight which was determined.

Experimental results. The amounts of RNA, protein, and lipid fractions prepared from the chromogranules were as follows:

Table I. Chemical composition of chromogranules

\begin{tabular}{|c|c|c|c|c|c|c|c|c|c|}
\hline$\frac{\text { granules }}{\begin{array}{c}\text { Chemical } \\
\text { components }\end{array}}$ & E-lem & d-lem & C-124 & hypodermis & E-lem & d-lem & $\mathrm{C}-124$ & Daizo & $W^{o x}$ \\
\hline$\underset{\mu \mathrm{g} / \mathrm{mg} \text { g.p. }}{\mathrm{RNA}}$ & 70.4 & 74.7 & 87.2 & $\begin{array}{c}\text { RNA } \\
\mu \mathrm{g} / \mathrm{mg} \text { d.m. }\end{array}$ & 51.9 & 49.4 & 65.5 & 56.9 & 79.6 \\
\hline $\begin{array}{c}\text { Lipid } \\
\mu \mathrm{g} / \mathrm{mg} \text { g.p. }\end{array}$ & 10.9 & 13.4 & 8.8 & $\begin{array}{c}\text { Lipid } \\
\mu \mathrm{g} / \mathrm{mg} \text { d.m. }\end{array}$ & - & - & - & - & - \\
\hline $\begin{array}{l}\text { Protein } \\
\mu \mathrm{g} / \mathrm{mg} \text { G. }\end{array}$ & 364 & 276 & 274 & $\begin{array}{l}\text { dry matter } \\
\mu \mathrm{g} / \mathrm{mg} \mathrm{H} \text {. }\end{array}$ & 297 & 324 & 296 & 290 & 280 \\
\hline Abbreviati & & $\begin{array}{ll}\mathrm{l}: & \mathrm{dr} \\
.: & \mathrm{ch} \\
\mathrm{G}: & \mathrm{ch} \mathrm{r} \\
\mathrm{H}: & \mathrm{hy}\end{array}$ & romos & $\begin{array}{l}\text { anule protein } \\
\text { anule } \\
\text { is }\end{array}$ & & & & & \\
\hline
\end{tabular}

In Table I, the amount of RNA is expressed by $\mu g \mathrm{RNA} / \mathrm{mg}$

*) Contribution from the National Institute of Genetics, No. 628 . 
protein of chromogranules, that of lipids by $\mu \mathrm{g}$ lipid/mg protein of chromogranules, and that of protein by $\mu g$ protein $/ \mathrm{mg}$ chromogranules.

It can be seen from Table I that quite a considerable amount of RNA is contained in the chromogranules. However, from our knowledge of the granules it may be said that it represents the RNA of ribosomal particles attached to the granular membrane.

For the study of the effect of ribonuclease on RNA contained in the chromogranules and in the hypodermal cells, $50 \mathrm{mg}$ of chromogranules of the lemon larvae or $100 \mathrm{mg}$ of powdered dry hypodermis of $\mathrm{C}-124$ and $w^{o x}$ were treated with $300 \gamma$ RNase at $37^{\circ} \mathrm{C}$ for 1.5 hours and then the amount of the remaining RNA in each of these samples was determined.

Experimental results are given in Table II.

Table II. The remaining RNA in granules and hypodermis treated with RNase

\begin{tabular}{c|c}
\hline $\begin{array}{c}\text { E-lem granules } \\
\text { RNase treated E-lem granules }\end{array}$ & $\begin{array}{l}70.4 \mu \mathrm{g} / \mathrm{mg} \mathrm{g} . \mathrm{p} . \\
28.3 \mu \mathrm{g} / \mathrm{mg} \mathrm{g} . \mathrm{p} .\end{array}$ \\
\hline C-124 hypodermis & $65.5 \mu \mathrm{g} / \mathrm{mg} \mathrm{d.m.}$ \\
RNase treated C-124 hypodermis & $23.5 \mu \mathrm{g} / \mathrm{mg} \mathrm{d.m.}$ \\
\hline WNase treated $W^{o x}$ hypodermis & $79.6 \mu \mathrm{g} / \mathrm{mg} \mathrm{d.m.}$ \\
Rypodermis & $16.5 \mu \mathrm{g} / \mathrm{mg} \mathrm{d.m.}$ \\
\hline
\end{tabular}

Abbreviations g.p.: chromogranule protein

d.m.: dry matter from larval hypodermis

As shown in Table II, the RNA in the E-lem granules was $70.4 \mu \mathrm{g} / \mathrm{mg}$ granular protein (g.p.), but was reduced to $28.3 \mu \mathrm{g} / \mathrm{mg}$ g.p. (i.e. $40 \%$ ) after treatment with RNase; thus, RNA contained in the granules was relatively resistant to RNase. Next, although the amount of RNA was $65.5 \mu \mathrm{g} / \mathrm{mg}$ in the dry matter (d.m.) from C-124 larval hypodermis, it was also reduced, to $23.5 \mu \mathrm{g} / \mathrm{mg} \mathrm{d} . \mathrm{m}$. (i.e. $35.9 \%$ ) after treatment with RNase. The amount of lost RNA in C-124 hypodermis is slightly larger than in the E-lem granules. On the contrary, the amount of RNA was $79.6 \mu \mathrm{g} / \mathrm{mg} \mathrm{d.m}$. in $w^{o x}$ larval hypodermis, but it was reduced to $16.5 \mu \mathrm{g} / \mathrm{mg}$ d.m. (i.e. 20.7\%). Thus, the amount of lost RNA in $w^{o x}$ hypodermis is much higher than in C-124 hypodermis.

Consideration. 1) Density of chromogranules; As described in our preceding paper (in press), the chromogranules produced in hypodermal cells of the transparent mutant larvae can be sedimented using 2.2 $\mathrm{M}$ sucrose solution which is more dilute than the medium used for the opaque normal larvae. The reason why we have to dilute the sucrose solution in this case seems to be as follows: As stated before, the vesicles of chromogranules contain soluble proteins 
combining either with pteridine pigments or with uric acid. It is possible on the basis of our studies of the developmental process of chromogranules in larval skin cells that larger amounts of those products can be accumulated in the granular vesicles of hypodermal cells of non-transparent normal larvae than of transparent mutant larvae; also the density of chromogranules is influenced by the concentration of products contained in the granular vesicles. Consequently, it is considered that the mature chromogranules produced in the hypodermal cells of non-transparent normal hypodermis have a higher density than those in transparent mutant larvae.

The density of mature chromogranules estimated from the concentration of sucrose solution in which the granules could be sedimented is 1.4-1.7. In Table III, the size and density of mature chromogranules in hypodermal cells of normal larvae are compared to those of other cell components such as microsomes, ribosomes, nuclei, and mitochondria which were estimated from rat liver.

Table III. Comparison of size and density of mature chromogranules to those of other cell components.

\begin{tabular}{|c|c|c|c|c|c|}
\hline $\begin{array}{l}\text { Cell } \\
\text { components } \\
\text { Density } \\
\text { and size }\end{array}$ & $\begin{array}{l}\text { E-lem mature } \\
d \text {-lem } \\
\text { C-124 }\end{array}$ & microsomes & $\begin{array}{c}\text { free } \\
\text { ribosomes }\end{array}$ & nuclei & mitochondria \\
\hline Density ( $\mathrm{g} / \mathrm{ml})$ & $1.4-1.7$ & $\begin{array}{l}\text { s. } 1.06-1.18 \\
\text { r. } 1.22-1.27\end{array}$ & 1.6 & 1.4 & -1.217 \\
\hline Diameter $(\mathrm{m} \mu)$ & $1000-1500$ & $\begin{array}{l}\text { s. } 50-300 \\
\text { r. } 50-100\end{array}$ & 15 & 6000 & 750 \\
\hline Abbreviation & $\begin{array}{l}\text { smooth endor } \\
\text { rough surfac } \\
\text { hypodermis }\end{array}$ & $\begin{array}{l}\text { lasmic reti } \\
\text { d variety }\end{array}$ & endopla & & $\mathrm{um}$ \\
\hline
\end{tabular}

2) Resistance of RNA to RNase in hypodermal cells of larvae. The results shown in Table II indicate that the amount of RNA resistant to RNase in normal $\mathrm{C}-124$ hypodermis is much larger than that in $w^{o x}$ hypodermis. On the contrary, a large amount of chromogranules are produced in hypodermal cells of C-124 larvae, but none are produced in hypodermal cells of $w^{o x}$ larvae. It is considered from those facts that RNA resistant to RNase in larval hypodermis may be related to the RNA of ribosomal particles attached to the granular membrane.

Summary. 1. RNA, protein, and lipids were prepared from purified chromogranules and the amount of the components was determined.

2. It is considered that the chromogranules produced in hypo- 
dermal cells of non-transparent normal or lemon larvae are more compact than those produced in transparent mutant larvae.

\section{References}

Mejbaum, W. (1939): Hoppe-Seyleis Z. Physiol. Chem., 258, 117-120.

Schneider, W. C. (1946): J. Biol. Chem., 164, 747-751.

Tsujita, M., and S. Sakurai (1966): Proc. Japan Acad., 42, 950-955 (1966). 